\title{
知識社会学から知識の実践学へ
}

\section{From a Sociology of Knowledge to a Praxiology of Knowledge}

\author{
中 村 和 生 \\ Nakamura Kazuo
}

This paper tries to demonstrate that relativism, scepticism, and anti-realism that theSociology of ( Scientific ) Knowledge inevitably assumes are logically difficult and not useful for empirical investigations. First, by way of Reductio ad absurdum, the Reflexive Programme is examined. Next, a relativist-sceptist orientation is grasped in the empirical studies of Sociology of Scientific Knowledge. This orientation is criticized from the standpoint of ethnomethodological studies of scientific work. A Praxiology of knowledge is proposed.

\section{1.はじめに}

知識社会学の営みを一言でまとめるなら、知識（生成）の社会的条件の研究ということ になろう(1)。しかし、その知識社会学も、当初、数学や自然科学を研究対象から除外する 方針を採ってきた。マンハイムは知識の存在被拘束性の適用可能な思考領域を、「内在的 な発展法則」や「純粋に論理的な可能性」ではなく、「存在条件」と言える諸々の「理論 外的条件」によって決定される領域としたからである [Mannheim 1929=1975:298]。科学 哲学からも、科学の心理・社会的研究に残されているのは、理論外の誤りなどの二次的な 問題だけであると論じられることもあった [Lakatos 1978=1986:174]。

科学的知識の社会学の創始者、D.ブルアは、このように除外されてしまった領域への社 会学の介入を理論的に根拠づけた。マンハイムが抱えた、数学や自然科学をめぐる知識社 会学の困難は、懐疑主義的なウィトゲンシュタイン解釈によって克服できるとブルアは論 じる [Bloor 1973]。ブルアは、デュエムークワインの「決定不全性のテーゼ」やハンソ ンの「理論負荷性」にそって、数学の公理でさえもそれじたいの観点からだけでは従うこ とができないこと [Bloor 1983:chap.5] や、(ラボアジェの酸素発見によって覆されるこ ととなった）プリーストリーが支持したフロギストン説も、ある目的からすれば実在との 満足な対応を成し遂げていること [Bloor 1976=1985: 50-4,197-9] などを主張していく。

このように、通常は客観的実在との精密な対応を根拠にして確立されたとみなされる自 然科学や、論理一貫性が必然とされる数学でさえも、文化的産物としての相対性の余地を 少なからず残していることを示すことによって、真偽に拘束されることなく科学的知識の 社会的条件を指摘し、因果的説明を行っていくことの可能性が説かれていく。科学におけ る真偽を決定するのは、科学それじたいではなく、その当の科学とは切り離して考えるべ きものとしての社会的なるものだということになる。

これにより知識社会学は新たな対象領域として「科学の実質的内容」を手にした。しか し、マンハイムへの挪揄 [Bloor 1973:179] にもかかわらず、その新たな領域へのアプロ 
一チの方法は決して変わっていない。科学的知識をその社会的条件から説明していくとい う試みは、「内在的な発展法則」や「純粋に論理的な可能性」ではなく、「存在条件」や 「理論外的条件」による思考領域の成立を明らかにしていくことに他ならないからである。

本稿は「科学の実質的内容」を対象化したことに、この知識社会学的態度の意義を認め ながらも、この態度では結局は当の対象を歪めてしまう必然性があることを示し、これに かわる方法的態度として、科学のエスノメソドロジー研究にもとづく知識の実践学を提唱 したい。本稿では、対象を歪めてしまうこの必然性は知識社会学に備わる相対主義や懐疑 主義、さらには反実在論(anti-realism)に由来するとみなす。そして、こうした主義(-ism)が 論理的に困難なものであり、社会学の経験的研究一般にとっても益するところが少ないこ とを示したい。

まず、知識社会学的手法の自己適用を一貫して進めた再帰的(reflexive)プログラムを、 背理法的手順をとって検討し、知識社会学に備わる根本的前提の誤謬を示す。次に、その 前提とみなされる相対主義的・懐疑主義的志向を科学的知識の社会学の経験的研究の中に 読みとる。その上で、それらの志向を科学のエスノメソドロジー研究にもとづき批判する。 そして最後に、知識社会学によらない方法的態度として知識の実践学を提唱したい。

\section{2. 再帰的プログラムのラディカルな展開}

ブルアが自らのストロング・プログラムを提唱するにあたって、「因果性・不偏性・対 称性・再帰性」という四つの原理を定式化したのは有名である [Bloor 1976=1985:7]。そ して、このプログラムの経験的研究においては、研究対象を「科学者集団」の「利害関心」 から準因果的に説明するという手法がとられた。この手法は、S.ウルガーによって、当の 原理の一つたる「再帰性」の観点から批判されることになる。

ウルガーは、自らの方針が「不偏性」の原理にもしたがったものであることを強調しな がら [Woolgar 1981b:511-512]、この説明手法の特性を分析し [Woolgar 1981a:388-389]、 さらには「再帰性」が招来する無限後退を避けたことに関してブルアを直接批判する [Woolgar 1983:255]。こうした展開をとおして、ウルガーは、四つの原理の中で特に「因 果性」から距離をとり「再帰性」を全面的に展開することによって、「不偏性」や「対称 性」を「被研究対象の実践」と「研究実践」との関係に適用したプログラムを切り開いた。 本節では、このプログラムの内実とその狙いを確認しておきたい。

この再帰的探求の典型例として挙げることができるのは、アシュモアによる事例研究 [Ashmore 1988:chap.4] である。その研究では、科学的知識の社会学における経験的相対 主義プログラムの創始者H.コリンズの主張が再帰的に検討される。コリンズは、自然科学 における実験の反復可能性は解䣋や交渉に依存するという知見を提出するが [Collins 1974]、この知見じたいは経験的相対主義者によって反復可能であり、そう要求すべきた と主張する [Collins 1983:92-3]。つまり、自然科学においては文字ど㧍りに捉えることの できない反復可能性が科学的知識の社会学においては成し遂げられるというのである。

アシュモアは、ウルガーの着目点にそって、コリンズの知見の反復可能性を検討してい る。さしあたり、ここで注目したいのはその検討の内実ではなく形式である。アシュモア は、コリンズの諸著作、インタビュー、手紙などを用いて、コリンズとの実際の対話や想 像上の対話を自らのテクスト内にちりばめる。想像上の対話も、時系列にそった会話を創 
りだす場合もあれば、（同時発話の目論見ともとれるように）頁の両端に対話を並べる場 合もある。反復可能性の検討は 6 段階に区別してなされるが、そのあいだに、コリンズの 知見の支持者と反対者の想像上の対話も挿入される。そして、各段階の検討が終了すると、 この自らの試み自体がコリンズの主張（知見の反復可能性）の候補になっているのかどう かを、自らが用いた同じ 6 段階の検討基準から考察している。さらには、最後も、反復可 能性の検討の結論が各段階から明らかであるのに、それを定式化するのではなく、自らの 分析結果に関するコリンズとの終りなき対話を創作することで締めくくられる。

またウルガーは、自らが編じた論文集において、その全ての論文の終りに省察(reflexion)を加えるという著述形式をとっている [Woolgar 1988a]。これは、論文編集者たるウ ルガーによって全て書かれているものの、この論文集の一貫性や連続性を主張するために 設けられたわけではない。むしろ逆である。それは各論文の著者の主張と混ざりあいつつ、 各テクストから発せられる声の多様性を強調するためになされているのである [ibid.:12]。

このようにして再帰的な態度を表明する著述形式は他にも多数ある(2)。ウルガーは、こ うした試みを、社会科学が自明視するとされる「表象のイデオロギー」[Woolgar 1988b: chap.7）というものに反対するための一つの方策と位置づける。この「イデオロギー」と は、研究対象がどんなものであれ、それがその表象に先行するという、いわば科学一般を 越えて自明視されている実在論的志向である。そして、この「イデオロギー」が、自らも 含めた社会構成主義者の相対化実践にも関わらざるをえないとウルガーはみなす。つまり、 「事実というものは先行的には存在しないが、構成作業によって構成される」と主張し、 その構成作業を記述するのなら、そうした記述に先行して構成作業が存在したという、 「表象主義的」コミットメントをすることになるからである。

これは相対主義のアポリアとしてしばしば指摘されてきたものに等しい。再帰的プログ ラムは、このような奇妙な著述形式を多様にとることによって、なんとかしてこの「イデ オロギー」から逃れようとする。よって、再帰的プログラムとは、少なくとも二つの意味 においてラディカルであろう。まず、自らの主張の相対化を、その当の主張と同時に行な う意味において。次に、自己分析によって自らの実践を危ういものとし、それに対する終 わりなき議論や無限後退を招来するという意味において、ラディカルである。

\section{3．科学的知識の社会学と相対主義・懷疑主義・反実在論}

以上のようなリフレクシヴ・プログラムが、マートンのように方法論的自己実現として 再帰性を掲げる合理主義的志向 [Merton 1978] への緩和策となることは確かである。し かし、この意義を認めつつも、ウルガーのリフレクシヴ・プログラムに見られるような新 たな著述形式を採用することは、それでも奇妙であることは否めない。

この奇妙な著述形式の採用はもち万ん偶然ではない。むしろ、最初の前提こそがあの著 述形式を導いたのではないか。その前提は、あるやり方では説得力を持って利用されたが ために、前提としての負荷の重みが認識されなかった。むしろ、こうした奇妙さを導いた ことによってその問題が極まったと言えるのではないだろうか。その前提は他なら奴知識 社会学に内在するものと考光られる。

そもそも知識社会学的態度には、研究対象の真理值を否定するという方向性があった。 たしかにマンハイムは相関主義が相対主義ではないことを強調している [Mannheim 1929 
=1976:59]。しかし、知識の社会的条件の指摘が必然的に相対主義を導くと考えられるか らこそ、それを克服するために相関主義が必要であることを強調せねばならなかったと推 考してよいだろう。もちろん、マンハイム自身は「 $2 \times 2=4$ という言明は、この言明が 誰によって、いつ、どこで、そのように定式化されたのかということを考えるわけにはい かない」 [Mannheim 1929=1975:305] と述べてお、数学や自然科学に対する懐疑主義を とったとはされない(3)。しかし、数学すらその社会的条件からの説明に服するとブルアが 主張した際には、規則に従うことに関する懐疑主義が不可欠であった。よって、知識社会 学的態度においては、研究対象が真理值に関わるものであればあるだけ、相対主義は懐疑 主義、さらには反実在論と結びつく。こうした主義を自己の研究プログラムにまで適用し たのが再帰的プログラムである。したがって、このプログラムの根幹にこれらの主義があ る。以下では、こうした主義がいかに知諳社会学的説明の拠り所やインパクトになってい るのかを確認したい。そのために、科学的知識の社会学の典型的な経験的研究を二つ取り あげたい。

最初に取りあげたいのは、H.コリンズの方法論的主張と経験的研究である。ストロン グ・プログラムと多くを共有する科学的知識の社会学者であるコリンズは、そのプログラ ムの原則の中で、「不偏性」と「対称性」をラディカルなものとして強調し [Collins 1983:87］、その立場から、脈動星（パルサー）発見の瞬間の天文学者の相互行為を分析 したガーフィンケルたちの論文 [Garfinkel, et al 1981] (以下、「パルサー論文」と略記) を批判している。

コリンズの批判の中で最も重要なのは「ある科学者のワークの何によって、彼らが偉大 な発見をしていることになるのかを知るには、そのワークの場面以外を見る必要がある」 [Collins 1983:105] という主張である。コリンズは「発見」として報告された事態が後に 間違いとされる場合などを指摘しながら、発見の手続きやその証拠についての知識を手に して録音テープから「発見」の瞬間の局所的歴史性をどんなに詳細に研究しても、歴史的 出来事としての発見には決して到達しないと主張する。

これに関連して、録音テープを主たる研究素材として用いることも批判されている。そ の録音テープは断片的で短く、発見の詳細を定める上でも情報が不足しており、ましてや ガーフィンケルたちは「その場」にいなかったわけであるから、テープの存在をもって特 権的な立場を主張することはあってはならないし、この類の事柄ならインタどューなどで も同様に入手可能であるから、こういった物神崇择的アプローチは慎むべきである、とい うかなり辛辣な批判が繰り広げられている [ibid.:110]。

こうした批判は、何が科学的発見を決定しているのかという問いを自然科学の基準から 切り離してたてることに躊躇しないなら、なにもコリンズ特有のものではない。数学や自 然科学を説明しようとする極めて多くの人文・社会科学者なら、通常同じ考えに至るだろ う。社会学的な説明を好むコリンズは、天文学の「共同体」の「合意」の形成過程を研究 する方が有意義であることを示唆している。

実際コリンズの経験的研究の中には、そのような「合意」形成に注目して、そこから社 会学的説明概念を抽出しているものがある。たとえば、彼の「TE Aレーザー」の研究に おいてもそのことが示唆されている [Collins 1974]。その研究によると、新種のレーザー が北米で発明されたという報告を知ったイギリスの実験物理学者たちは、このレーザーを 
自分の実験室で作りあげることに取りかかったのであるが、文献上に報告された技術的知 識だけではその製造は不可能だった。そこで、各々の実験室は、発明が行われた実験室と 何らかのコンタクトを取ることで製造を成功させようとしていった。

この事例は、製造された個々のレーザーのどれが、まさに本物のレーザーとして是認さ れるのかは「有力な判定者」によっていたという指摘のゆえに注目された [Mulkay 1979 =1985:164］。コリンズによれば、製造の成功を競い合っていた各々の実験室は情報提供 その他の協力を差し控えていたが、たった一つの実験室だけが、北米との関わりを含めて、 各実験室の進行状況などの情報を他の実験室に提供していたのである。

この点からコリンズは、その実験室が、たんに製造上の観点から優勢であるばかりで なく「その威信(prestige)はイギリスの諸大学（の実験室）から傷つけられることが全くな いように思われる」[Collins 1974:180-1] と推論する。つまり、この威信ゆえに、その実 験室は他の各々の実験室に対して支配的な力を保持しているという説明が可能になるので ある。この事例から「有力な判定者」というカテゴリーをくくりだし、判定の技術的基準 とは区別される「社会的」基準を提出し、それを説明項として強調することが、彼らの研 究が他ならぬ知識社会学であるということをあからさまにしている(4)。

そして、この判定の「社会的」基準の強調の中に技術的基準に対する相対主義的・懐疑 主義的志向が見うけられる。コリンズの強調点をくみとるなら、技術的基準によってはど れも「本物のレーザー」にはなれないし、また同時にどれでもなる資格を持っていると容 易に読めてしまうからである。こうした観点から、ガーフィンケルたちの研究においては そのような説明が「抜け落ちている」というような非難がなされているのである。

次に、実験室研究の記念碑的著作たる『実験室生活』[Latour \& Woolgar 1979] を取り あげたい。そして特に彼らの方法論的前提に注目しながら、それによって生み出される懐 疑主義的志向、更にそこから引き出される反寒在論的読解を確認しておきたい。

B.ラトゥール\&S.ウルガーは、A.シュッツやG.ジンメルの議論と同様に、観察者が「他 所者」であることが観察対象の把握にとってむしろ利点であると主張する(5)。彼らは様々 な観察記録をとおして、およそ実験室にあるものはすべて「インスクリプション」として 元々の実体と直接の関係を持ち [Latour \& Woolgar 1979:51]、実験室の内部構造じたい も多くの図やダイグラムを含んだ論文を産出していくように組織されていると主張する。

ここで彼らが強調するのは、その組織化のあり様じたいがいかに秩序だったものである のかということではなく、むしろそれとは反対に、実験室とは通常「無秩序な」なもので あり、その無秩序状態は、インスクリプション装置によってテクストのレベルへと改変さ れることで始めて秩序だったものになるということであった [ibid.:27-36, 252-8] 。

このようにして実験室を無秩序とみなしたことの損失はかなり大きいものであったが(6)、 本稿で注目したいのは実験室を無秩序とした際の彼らの方法論的前提である。それらは、 この著作の序論と結論にある。結論では、J.マクスウェルの逸話やボード・ゲームを用い て実験室の無秩序性が比喻的に語られるが、序論では、ウルガーの研究事例である脈動星 発見に関する記述 [Woolgar 1976] を例として無秩序性が論じられている点が興味深い。 その議論では、脈動星発見に関する記述が賞賛とも非難ともとれることから、記述はどの ようにでも解秎することができ、さらには「原理的には、どの代替案も疑うことができる」 [Latour \& Woolgar 1979:35] ということが強調されているのである。 
こうした解釈の無限性が相対主義にもとづくものであるのは明らかであるが、ブルアの 議論と同様、自然科学のように発見の真理性に重きを置く領域の分析において解釈の無限 性が強調されるのであれば、それは発見への懷疑主義的な態度であり、さらには発見され た対象に対する反実在論とも結合すると理解されるのは当然であるかもしれない。

『実験室生活』の反実在論的な読解が可能な箇所として最も有名なのは、彼らの観察対 象たる自然科学者の発見物であるTRF（甲状腺刺激ホルモン放出因子）が「徹頭徹尾社会 的構成物である」[ibid.:152] という主張である。この主張を「人工的なリアリティという ものは、実験の参与者によっては客観的実体という観点から記述されるけれども、実際に はインスクリプション装置の使用によって構成されたのである。 [ibid.:64］という主張と あわせて考えれば、きわめて反実在論的な主張となる。I.ハッキングは、この文の「人工 的(artificial)」と「客観的」が対立項として表現されているととれる点ではラトゥール＆ウ ルガーは科学的実在論に反対する論者であると述べている [Hacking 1988:285]。「構成」 という語も、こうした文脈では「実在」との対比で理解されても仕方ない。もちろん、 『実験室生活』の内実をその方法論によってだけ判断するのは公平でないが、彼らの全体 的な論調が相対主義や懐疑主義、さらには反実在論までも寄せつけるものであるのは否め ない。そして「最初の実験室研究」として出版された本において反実在論ともとれる議論 が展開されたことがいかにインパクトを持ったのかを想像するのは容易い(7)。

\section{4. 科学実践内現象としての懐疑的態度}

本節では、「パルサー論文」へのコリンズの批判に対するM.リンチの再批判 [Lynch 1992:247-256] を参照して、相対主義／懐疑主義に対する批判を展開していく。第一に、 コリンズの批判を再検討し、相対主義や懐疑主義が、科学的知識の社会学が事例研究を行 っていくに際して論理的な䛊謬を犯していることを論じる。第二に、脈動星発見の論文に たち返り、懐疑的態度の位置づけをする。この懐疑主義的志向は社会科学者が拠り所とす るものではなく、実験実践を構成する一つのリソースにすぎないことを示す。

\section{（1）懐疑主義的議論のトリック}

まず、コリンズのガーフィンケル批判から考えたい。発見とされてきたことが後になっ て否定されるという想定には、ストロング・プログラムと同様の懐疑主義的な志向が既に ある。算術の規則があるだけではその規則に従うことができない、という見解から引き出 されたのは、数学それじたいとは別の観点、すなわち共同体の「抑制」「合意」といった 説明要因である [Bloor 1983=1988:138-9] 。しかし、そのために、規則の定式と規則に 従う活動の内的な関係 [Sharrock \& Button 2000] が切り離されたのである。

この規則の議論と同様の展開をみせている点で、コリンズは、ブルアと同様に、発見に 関して懐疑主義的議論を引き寄せている。また、算術の規則よりも発見の方が「共同体の 合意」をより実体的なレベルで想像しやすいので、そこから説明概念を引き出すのも容易 である。リンチは、発見された対象とそれを発見たらしめている一連の行為との内的関係 を切り離す点では、実在論者も懐疑主義者も変わらないが、発見の行為の表象として書か れた報告が発見された対象を構築するのだという懐疑主義的主張によって、実在論者の議 論は反転させられる、と指摘する [Lynch 1992:251]。つまり、規則の「言明」ではその 
馴染みの規則に従う活動を決定できないという議論と同様に、脱状況化された「報告」の どれが発見された対象の報告であるかを決定できるのは、発見活動以外の何かでなければ ならないということになってしまう。これを所与とするのなら、発見「報告」の是非は、 天文学の「共同体」による、天文学的基準と切り離された「社会的」基準によって決定さ れるという反常識的な主張がいともたやすく帰結するのである。

リンチが主張するように [ibid.:253]、そのような「社会的」基準から天文学の「共同体」 が発見の「報告」を「承認」するまで、どんな天文学者も発見を行うことができない、と いうコリンズの主張はトリックである。コリンズやブルアの好む「共同体」のアナロジー を続けてみれば、このことは一層明らかになる。まず、天文学の「共同体」が判断するの は発見の「報告」だけではない。発見の同定をめぐっては、発見手続きそのものが全て考 察対象となる。発見の是非に必要なのはその手続きの遂行や理解可能性である。つまり、 「共同体」が判断を下す審議室は観測室でもなければならない。次に、その審議には判決 を下す裁判官は存在せず、存在するのは陪審員による審議だけである。よって、論理的に は、天文学的基準ならざる「社会的」基準から「共同体」の「権威者」が介入する余地は ない。このことは経験的事実によっては覆されえない。つまり、そうした事実があるなら、 それは天文学的基準が順守されなかったことを示すにすぎないのである。

もちろん、それでも「共同体」のアナロジーを維持することは可能である。しかし、 「共同体」の判断は、もはや諸成員の天文学的行動と切り離すことはできない以上、誤解 を招くものでしかない。知識社会学に由来する相対主義を一貫して行使し、行為の「説明 要因」を社会学特有のものとして構築するために、コリンズたちはこのトリックをどうし ても必要としたのである。しかし、ガーフィンケルらの研究によるトランスクリプトを丹 念に追っていき、彼らの議論を検討するなら、実験室の活動による発見の同定作業の実際 は、そのような知識社会学的説明に耐えうるほど従順なものではない。

\section{（2）「パルサー論文」再考}

脈動星発見の瞬間を取りあげたガーフィンケルたちの狙いは何だったのか。懐疑主義の 誤謬から考えていきたい。規則の定式に適切な意味が与えられるのは、そのルールに従っ て実際に活動を行うことにおいてである。全く同様に、発見の報告論文は、その報告が定 式化している実際の活動の秩序に携わることにおいて、はじめて適切な意味を持つ。ブル アやコリンズのように、定式や報告を、それを用いる活動と切り離すことは、丹念に培わ れた樹木をわざわざ根こそぎ掘り起こし、枯らせるようなものである。

つまり、ある発見を説明する要因がかりに必要とされるとしても、それは、相対主義に 由来する社会学的説明要因ではなく、発見手続きにそった対象への介入過程の中に求めら れなければならない。社会学が説明を行うという実践を行う以前に、そしてそれとは全く 別に、発見は既に達成されている。もち万ん、発見それ自体に関して社会学が行うことは それでも残っている。それは、科学者自身が同僚なら誰にでもわかるように、自分が行っ たことが発見なのだということを、まさにその発見のただなかで理解し、理解させていく ことを記述し、その特性を分析することである。

実際ガーフィンケルたちは、そのような記述・分析を試みたのである。観察の初期にお いて、スクリーン画像上のパルスに関して取り交わされている天文学者たちの会話を見て 
わかるのは、一方の天文学者はその当初から「それ」がパルサーであると確信して興奮し ているが、もう一方の天文学者はそれに「懷疑的な」応答をする。たとえば、発見を確信 している天文学者がチーフに発見を電話で伝えることを促した後も、懐疑的な天文学者は、 器具の調整を頼んで、「それ」が人工物でないかと再三にわたり疑っているのである(8)。 発見の真理性をめぐる疑問は哲学者や社会学者が自由に操れるものではない。それはその 晚にその場で発見作業に携わる自然科学者の、その都度進行していく一連のやりとりの中 で提出され、そして受け入れられたり、拒否されたり、留保されたする事柄なのである。 つまり、一連のやりとりの中で使用されていく懷疑に他ならない。

その数回の確認後に懷疑を示していた者も確信にいたるが、発見作業はまだ終了しない。 発見の報告を何時すべきなのか、どのように呈示すれば、単なる「確信」でなく「発見」 として是認されるのか。これらの課題を克服していくために、その後の入念な作業がテー プが終了しても続いていることは当然想定できる。発見とは、この局所的な歷史性の全て において、その全てから成るものとして、発見者がそこでの過去を振り返り、未来を予期 しながら達成されていくものなのだということも、ガーフィンケルたちは主張している。

たしかに、この局所的歴史性すべてを入手できるのは実践者をおいて他にはいない。ガ ーフィンケルたちはその実践活動の一端を提示しているにすぎない。しかし、この局所的 歴史性は決して無視できない。というのも、このような局所的実践がこの一端に限らず行 われているのは疑いえないことであるし、この局所的実践なくして発見は成立しえないか らである。たしかに発見というものは「報告」にまとめることが可能な事柄であるが、そ の「発見」をまさに発見にしているのは局所的な実践活動であり、その秩序なのである。 これらがインタビューによって入手可能である保証はどこにもない。

ラトゥール\&ウルガーとは反対に [Latour \& Woolgar 1979:244-252]、こうしてガーフ インケルたちが見出したのは、観測室における活動が秩序だっていることであり、そして この秩序性は終わりなき日常性におけるものに他ならないということであった。そのトラ ンスクリプトには、「雄叫び」が何回もなされていたり、いくつもの「それ」が発されて いる。こういった感嘆詞や指標的表現が「無秩序」となるのは、それらが「科学的合理性」 という理念にもとづく科学活動と対照させられる場合をおいて他にはない。もちろん天文 学者たちは、諸々のインスクリプションによって手にした結果を「発見の告知」や「論文」 にしていく活動に従事していく。しかしながら、そうした活動ですら、観測室の秩序だっ た実践があればこそ、それに引き続いて行うことができるのである。

よって、科学者たちの実践というものは殊更に疑われる余地のないものである。まして や、他所者によって相対化されたり無秩序にされたりして、懷疑に服するような現象では ない。そしてガーフィンケルが揭げたトランスクリプトからわかるのは、観測の過程にお いて、何かが疑わしいという事態が訪れるということである。そして、この事例とは異な って、そうした懷疑が、一日の作業のやり直しから、調査研究プログラムじたいの頓挫に いたるまで、実践上の重大な帰結をもたらすこともあるだろう。

しかし、こうした懷疑を契機とする様々な失敗は、科学実践一般が科学哲学者や科学社 会学者によって予め全面的な懐疑を受ける対象となることには決してならない。むしろ、 懐疑的態度というものを科学実践の中に返してやることを納得させてくれる。同僚の主張 を批判してみたり、観測結果を疑ったり、そして時には、科学的対象の表象が実在を反映 
しているものではないとして観測や実験をすべてやり直すという作業において、懐疑的態 度は見てとれるのである。それは、科学的対象を精密に厳格に探求していくという科学実 践の中において使われる一つのリソースにすぎない(9)。

そして、科学的対象の探求があくまで実在論的志向に根差したものである以上、実在論 的志向も懐疑的態度も、科学実践にとって不可欠の両輪なのである。これらは社会科学者 によって「イデオロギー」として斥けられるものではなく、一連の実践活動の中において、 状況に応じて採られていき、そのようなものとして観察可能な事柄なのである(10)。

\section{5. 知識社会学から知識の実践学へ}

最後に、こうしたガーフィンケルたちの探究が知識の社会的研究として持つ方向性を、 若干ながら描いておきたい。この研究は、知識の社会的基盤を指摘することで、その知識 の真理値を格下げすることに反対する。前述したように、ガーフィンケルたちは発見を可 能にしている社会的条件を提出しょうとはまるで考えない。彼らの問いは「その晚の天文 学者のワークとしてパルサーは何から成るのか」[Garfinkel, et al. 1981:132] であった。 つまり、この問いを真剣に考えるのなら、発見活動における、そしてその活動そのものか ら成るものとして、発見はいかにして達成されているのか、というものになる。よって、 社会的条件の真実性を必ずしも拒絶するわけではないけれども、それらの列挙に終始して は、発見活動じたいが持っているこうした社会性が失われてしまうことが理解できる。

この発見活動じたいの社会性を明確にするために、コリンズ自身の研究にたち返りたい。 その研究ではレーザーの製造の成功の是非に関して「有力な判定者」の存在が強調されて いたが、そればかりでなく製造にあたって「直接の個人的接触」[Mulkey ibid.:161] が果 たす役割も主張された。さらにコリンズは、公表された技術的知識の不十分さは暗黙の知 識が把握されていたかどうかが原因となっていることを述べている [Collins 1974:177]。

ここで注目すべきなのは、そのような知識を社会的ならざる、もう一つの基盤として定 式化していく必要があるということではない。それでは、社会的条件からの疑似因果的説 明とさして異なるところはない。むしろ、公表された技術的知識も暗黙の知識も、それが ある場で使用されていく、その成り立ちと切り離して考えることはできないことに注目す ベきである。すると、レーザーを製造するという活動における秩序性に注目することにな り、コリンズのこの研究にガーフィンケルらの研究との接点を見出す可能性が開ける。

それゆえ、レーザーを製造するという活動を、その製造者の役割を強調するあまりに 「個人的性格」を有するものとしてコリンズが表現したのは誤解を招きやすい。レーザー を製造するという活動は、数人で行われようとも個人によって行われようとも、他人に入 手不可能な現象ではない。もしそうであるのなら、その製造についてのあらゆる議論はほ とんど意味をなさない。強固な主観性も同じく拒否されるべきである。私的言語の不可能 性と同㥞に、この活動も公的な観察・理解可能性を備えており、その意味で社会的なので ある。

そして、こうした社会性、発見活動の秩序性の公的な観察・理解可能性への注目こそが ガーフィンケルが提唱するエスノメソドロジー研究の独特さなのである。実践活動それ自 体の理解可能性を社会的なものとみなすガーフィンケルらの論点は、知識社会学に由来す る社会的条件の指摘とは根本的に袂を分かつ。つまり、実践における調和を共同体の合意 
その他の条件にすりかえることによって社会学特有の説明要因を築いていく知識社会学の 主張とは完全にすれ違っているのである。

ガーフィンケルらの論点からすれば、実験室内の活動に注目するのであれ、実験室外の 科学的営為に注目するのであれ、従来の社会学が築きたいような疑似因果関係を成り立た しめる社会的要因がそうした実践活動の詳細のレリヴァンスに入り込む余地など、ほとん どない。さらには、そうした社会的条件を指摘することを可能ならしめる全面的な相対主 義や懐疑主義を採るのであれば、逆に、当の対象を歪めることになるのである。そして、 これらのことを把握することこそが、実際の活動の秩序性の観察・理解可能性が問うに值 する一級の社会現象なのだということを知識社会学に気づかせてくれるのである。

この理解可能性の探究を「知識の実践学」と呼べると思う。それは、第一に、知識の社 会的基盤を指摘するのではなく、知識それ自体を社会的なものとみなす点で知識社会学と 大きく異なる。そして第二に、その知識を、知識内容としてだけでなく、知識産出のあり 様やその公的な観察・理解可能性として捉えている点でも知識社会学と大きく異なる。

この第二の点は、ガーフィンケルたちが天文学に習熟していないにもかかわらず、断片 的で短く、情報の不十分な「テープ」から聞き取れることによって知識産出のあり様を分 析したという事実に最もよく現れている(11)。もちろん、テープが録れれば、それが完壁 なデータとなるわけではない。それは社会科学者の単なる手段であり、データというより は断片である。また、扱いたい現象や問題関心に応じて、テープの地位も様々であろう。

しかし、我々の社会は、もっぱらその断片において、そしてその断片から成るものとし て、その都度その都度、瞬時の連なりをとおして達成されている。このことは発見テープ のトランスクリプトからでも理解できるし、これこそが実際の活動の秩序性の観察・理解 可能性の一端そのものなのである。そのようなその都度の達成と、それについてのインタ ビューを等価とし、この達成を離れるのなら、この知識産出のあり様は、観察可能なもの であり公的に理解可能であるにもかかわらず、消え失せてしまうのである。

この知識の実践学的態度は現在の社会学的方法の模索 [内田 2000] にたいする一つの 答えになっているのではないだろうか。科学的知識の社会学は、社会学をする際の「基礎 づけ」の方向性を、再㷌的な自己適用によって打破した。この意義を認めつつ、知識の実 践学は、相対主義・懷疑主義の論理的誤謬を示すことによって、終わりなき「再帰性」の 方向性をその根源から断ち切る。「基礎づけ」も過度の「再帰性」もそもそも不要であり、 さしあたり様々な場における実際の活動の秩序性の常識的な観察・理解可能性を出発点と する研究の道がすでに開かれているのである(12)。

注

(1) 本稿においては、知識社会学を特にマンハイムによる定式 [Mannheim 1929] から捉えたい。よっ て、P. バーガー\&T.ルックマンによって大幅な修正を施された再定式は、論点がほやけるので考察対 象外とする。

(2)［澤井 1995］参照。アシュモアは同じ著作の中でパラレル・テクストという形式も用いている [Ashmore 1988:chap.6]。これは一つのテクストの中で二人の著者が同時に議論を展開するものであ り、一方の著者の節が終るともう一方の著者の節が介入してくる。第二の著者は第一の著者の直前の 主張を支持したり批判したりする。第二のテクストは、言わばメタ・テクストとして働いている。し かし、メ夕・テクストがテクストを支配するわけではない。最後には、両著者の最終同意なき対話が 
おかれ、この章は幕を閉じる。

(3) この点の詳細な検討としては [Lynch 1993:41-54］を挙げることができる。

(4) ただし、そのような判定者や一般基準がないとする事例もコリンズは論じている。この点において、 コリンズは、ブルアと同種の社会学主義を採りながらも、研究の方向性を若干であるが異なものにし ているように思われる。そのような研究として、たとえば、[Collins \& Pinch 1978] を挙げることが できる。

(5)この主張はかなり疑わしい。彼らは「人類学的に奇妙な」ものとして対象を見るという、もともと ガーフィンケルが用いた表現を用いて自らの利点を保証しょうとしている。しかし、ガーフィンケル は「他所者」というアイデアを、未知の現象の解明に携わる「研究者」の方法論上の利点でなく、既 知の現象の解明のための助力として用いて様々な期待破棄実験を行ったのである。もちろん、ある対 象が何であるのかを同定していく実践においては「無秩序」と言ってもよいような、渾沌とした対象 把握の状況が存在するであろう。しかし、この「無秩序」と「他所者」が単に実践を理解し損なって いることを並べて等価にするのは間違っている。他所者の利点は、その者が「場の実践者」というカ テゴリーも「他所者」というカテゴリーも担えるようになって始めて生まれるものだろう。最終的に 彼らは、自分たちの理解が実践者たちと何ら異なるものでなくなったことを述べるが [ibid.:256-7]、 これは「他所者」の認識上の利点によるわけではない。

(6) 『実験室生活』とは異なり、リンチの実験室研究である『アート\&アーティファクト』には実験活 動が詳細に記述されている。これに関しては［中村 2000］にて検討した。

（7）こうした傾向にもかかわらず、注意深い読解と好意的な態度を持つのなら、『実験室生活』が反実 在論を打ち出しているという解釈を採用する必然性はない。ハッキングじしん、ある種の実在論的観 点から『実験室生活』を捉え直すべきであるという議論を展開している。ラトゥール＆ウルガーは、 科学者の発見した対象が「発見を待ちわびていた『自然の事実』」であるとみなすことを拒否してい る。ハッキングはこの拒否を、実験科学における「現象の創造」[Hacking 1983:chap.13]という視点 と結びつけることで、彼らの主張する「科学的事実の構成」が反実在論的なものにならないことを示 している。また、現象を創造していく装置の解明に関わる彼らの主張を評価し、自らその点を補う経 験的検討も加えている。

（8） ガーフィンケルらが揭載している'Observation 19'［Garfinkel,et al.1981:150-3] のトランスクリプト を参照。

（9）「発見」とされていた事柄が後に否定されるのも、それ自体また一つの実践的達成である。その場 合に社会学者がなすべきことは、発見の同定に関する研究と何ら異なるものではない。つまり、「『発 見』とされていた事柄が後に否定される」という実践活動がいかに織りなされているのか、このこと こそ社会学者が例証・解明できることなのである。また、発見の誤認が確定したことによって実験室 での活動が無視されるわけでは全くない。むしろ、その逆であろう。たとえ理論的前提の変革によっ て発見が破棄された場合でも、そのことは実験室における個々の活動との関係性をもたねばならない。 もちろん、理論と観測の関係は一一意的に表現するのは困難にしても一単に個々別々に考えることが できないのだが、観測されたデー夕を「理由なく」無視することも不可能である。ならば、コリンズ とは逆に、「科学的ワークの場面においても、『場面外の知識』ですら、その場面特有に用いられる」 という主張の方がーそのことによって科学活動は実験室でしか行われえないということが含意される ことなく一的をえたものとなるだろう。

(10) インタビューという手法によってであるが、こうした実在論的志向と懐疑的態度という点を発展さ せたのが、マルケイ\&ギルバートの「経験主義的レパートリー」と「偶然的レパートリー」による誤 謬説明との対比である。彼らの問いの立て方にはガーフィンケルの影響がみてとれる [Mulkay \& Gilbert 1984=1990:30]。

(11) ただし、ガーフィンケルたちは、当の天文学者へのインタビューも行っているし、その発見の報告 も論文に揭載している。これらを実験実践の理解可能性の「助力」として考えることができる。助力 だとみなすのは、一方の天文学者が懷疑的な態度をとっていることなどがそうした助力なしでも理解 可能だからである。 
（12）たたし本稿では「全体性としての『社会』」への態度を明示的には表明していない。知識の実践学 は、こうした「社会」をカテゴリー的／実践的達成とみなした上で経験的研究を展開する。[中村 1995］参照。

\section{参考文献}

Ashmore, Malcom 1988 The Reflexive Thesis. The Univ. of Chicago Press.

Barnes, Barry 1981 "On the 'hows' and 'whys' of cultural change," Social Studies of Science (11):481-98.

Bloor, David 1973 "Wittgenstein and Mannheim on the sociology of mathematics," Studies in History and Philosophy of Science (4):173-191

— 1976 Knowledge and Social Imagery. Routledge. 佐々木他(訳)『数学の社会学』 培風館 1985.

1983 Wittgenstein: A Social Theory of Knowledge. Macmillan. 戸田山(訳)『ウィトゲンシュタ

イン：知識の社会理論』勁草書房 1988.

Collins, Harry 1974 "The TEA set: tacit knowledge and scientific networks," Science Studies(4):165-85.

- 1983 "An empirical relativist programme in the sociology of scientific knowledge,"

Knorr-cetina\& Mulkay (eds.), pp.85-113.

1985 Changin Order. Sage. $\rightarrow$ Univ. of Chicago Press.

\& Pinch, Trevor 1978 "The construction of the paranormal: nothing unsientific happening," Wallis, Roy(ed.), Rejected Knowledge. Univ.of Keele 高田他(訳)『排除される知』青土社 1978.

Garfinkel, Harold 1967 Studies in ethnomethodology. Prentice-Hall.

Garfinkel, et al. 1981 "The work of discovering science construed with materials from optically discovered pulsar," Philosophy of the Social Sciences (17):131-58.

Hacking, Ian 1983 Representing and Intervening. Cambridge Univ.Press.渡辺（訳）『表現と介入』産業図書 1986.

- 1988 "The participant irrealist at large in the laboratory," British Jornal of Philosophy of Science (39): 277-294.

1999 The Social Construction of What? Harvard Univ. Press.

金森修 2000 「社会構成主義の興隆と停滞」in『サイエンス・ウォーズ』 東京大学出版会

Knorr-Cetina, Karin \& Mulkey, Michael(eds) 1983 Sceiencs Observed. Sage.

Lakatos, Imre 1978 The Methodology of Scientific Research Programmes. Cambridge. 村上他(訳)『方法の 擁護』新曜社 1986.

Latour, Bruno 1987 Science in Action. Harvard Univ. Press. 川崎・高田(訳)『科学が作られている時』 産業図書 1999.

— \& Woolgar, Steve $1979[\rightarrow 1986]$ Laboratory Life. Princeton Univ. Press.

Lynch, Michael 1979 $\rightarrow 1985$ Art \& Artifact in Laboratory Science. Ph.D $\rightarrow$ Routledge \& Kegan Paul.

1982 "Technical work and critical inquiry," Social Studies of Science (12):499-533.

1992 "Extending Wittgenstein: The pivotal move from epistemology to the Sociology of Science,"

Pickering, Andrew(ed.), Sceience as Practice and Culture. Univ. of Cicago Press.

1993 Scientific Practice and Ordinary Action. Cambridge Univ. Press.

- 2000 "Against reflexivity as an academic virtue and source of plivileged knowledge," Theory, Culture \& Society (17-3):26-54.

Mannheim, Karl 1929 “Ideologie und Utopie” 樺(訳)「知識社会学」(マンハイム全集第 2 巻集録) 1975、 樺(訳)『イデオロギーとユートピア』(マンハイム全集第 4 巻) 潮出版社 1976.

Merton, Robert K. 1978 "The sociology of science: an episodic memoir," Merton \& Gaston,J.(eds), The Sociology of Science in Europe. Illinois University Press., pp.3-14.

Mulkay, Michael 1979 Science and the Sociology of Knowledge. George Allen \& Unwin. 堀他(訳)『科学 と知識社会学』 紀伊國屋書店 1985 . 
\& Gilbert, Nigel 1984 Opening Pandora's Box. Cambridge Univ. Press 岩坪他(訳)『科学理論 の現象学』紀伊国屋書店 1990.

中村和生 1996 「理論化作業の実践学的探究」『年報社会学論集』(関東社会学会) 10:181-192.

2000 「テクノサイエンスとエスノメソドロジーの接点：インスクリプション」『現代社会理論 研究』10：267-280.

奥田栄 1993 「科学社会学における相対的構成主義への批判」『年報 科学・技術·社会』 $2: 95-114$.

澤井＼cjkstart敦 1995「相対主義とリフレクシヴィティ」『社会学史研究』 $17: 37-53$.

Sharrock, Wes \& Button, Graham 2000 "Do the right thing! Rule Finitism, Rule Scepticism and Rule following” 池谷(訳)「正しいことをなさい!」『文化と社会』2：99-123.

内田隆三 2000 「社会学の思考と全体性の問題」第73回日本社会学会 (於広島国際大学) シンポジウム 1 : 理論系譜の横断 — 19世紀/20世紀社会学報告要旨 pp.381-2.

Woolgar, Steve 1976 "Writing an intellectual history of scientfic development: the use of discovery accounts," Social Studies of Science (6):395-422.

— 1981a "Interests and explanation in the social studies of science," Social Studies of Science (11) :365-394.

1981b "Critique and criticizm," Social Studies of Science (11) :504-14.

1983 "Irony in the social studies of science," Knorr-Cetina \& Mulkey (eds), pp.239-66.

36.

1988a "Refrexivity is the ethnographer of the text," Woolgar(ed.) Knowledge and Reflexivity. Sage., pp.14-

1988b Science: the very idea. Ellis Holiwood Limited.

(明治学院大学他非常勤講師) 